\title{
HISTORISITAS KISAH FIR'AUN DALAM PERSPEKTIF ISLAM
}

\section{Effendi}

Universitas Islam Negeri Raden Intan Lampung

effendiuinlampung@gmail.com

\begin{abstract}
The focus of this article is to reveal the pharaoh's description that is revealed in the texts of the Qur'an. The research approach used is the bistorical approach of Fazlur Rahman. Based on the results of the study, the following conclusions are found: First, Fir'aun according to the Koran is the rulers who in carrying out their government using an oppressive system, this oppression is supported by its authorities. Second, the mission carried by Moses is the Liberation of the Children of Israel from the chains of oppression and slavery. The Children of Israel as Mustadl'afin in the story need to be addressed with the current context, because the term Mustadl'afin is not only found in the time of Pharaoh but always in every level of society, so that concrete steps are needed to release from the grip of the oppressors. Third, the Story of Fir'aun cannot be understood as we read texts in history, because in it many moral ideas must be raised amid the dilapidated oppressive system.
\end{abstract}

\section{Abstrak}

Fokus artikel ini adalah mengungkap gambaran Fir'aun yang diungkapkan dalam teks-teks al-Qur'an. Pendekatan penelitian yang digunakan adalah pendekatan historis Fazlur Rabman. Berdasarkan hasil penelitian, ditemukan kesimpulan sebagai berikut: Pertama, Fir'aun menurut al-Qur'an adalah para penguasa yang dalam menjalankan pemerintahanya memakai sistem yang menindas, penindasan ini didukung oleh para pembesar-pembesarnya. Kedua, Misi yang diemban oleh Musa adalah Pembebasan Bani Israil dari belenggu penindasan dan perbudakan. Bani Israil sebagai kaum Mustadl'afin dalam kisah 
tersebut perlu disikapi dengan konteks kekinian, karena istilah Mustadl'afin bukan hanya terdapat pada masa Fir'aun tetapi selalu ada disetiap lapisan masyarakat, sehingga diperlukan langkah kongkrit untuk melepaskan dari cengkeraman para penindas. Ketiga, Kisah Fir'aun tidak bisa dipahami seperti kita membaca teks-teks dalam sejarah, karena didalamnya banyak sekali ide moral yang harus dimunculkan ditengah bobroknya sistem yang menindas.

Keywords: Historicity, The Story of Pharaoh, Al-Qur'an

\section{A. Pendahuluan}

Al-Qur'an dipilih sebagai subjek kajian dalam penelitian ini dengan beberapa alasan karena kitab suci ini diyakini sebagai sumber utama ajaran islam yang harus terus menerus digali kandunganya agar secara praktis dan teoritis selalu menjadi pandangan hidup. Berangkat dari kegelisahan betapa interaksi sebagian umat islam dengan alQur'an, masih terbatas pada keyakinan, membaca dan mendengarkan, belum banyak yang sampai pada mempelajari secara mendalam.

Sebagai akibatnya, mutiara kandungan al-Qur'an belum tergali dan lebih lanjut al-Qur'an belum menjadi fungsional -secara optimal-sebagai petunjuk. Sehingga wajar kalau kemudian umat islam jarang yang menjadikan al-Qur'an sebagai dasar pijakan dalam bertindak dan bersikap. Tanpa disadari hal ini akan menjadikan alQur'an hanya simbol semata dan menjadikanya sebagai barang antik. Oleh karena itu upaya-upaya untuk memahami dan menafsirkan alQur'an harus terus kita kembangkan dengan berbagai perspektif dan pendekatan untuk menghasilkan sebuah konsep yang sesuai dengan kandungan al-Qur'an dan selanjutnya diterapkan ditengah problem masyarakat yang semakin beragam dan kompleks.

Sejak semula al-Qur'an sudah diprogram sebagai kitab yang berisi ajaran-ajaran yang dijadikan petunjuk ${ }^{1}$-bukan hanya pada masyarakat ketika dan dimana ia diturunkan -tetapi juga untuk masyarakat keseluruhan sampai akhir zaman, juga sebagai kitab yang bersifat transhistoris, tidak dibatasi ruang dan waktu baik sejak Adam

1 Sebagaimana Firman Allah: Artinya: "Beberapa hari yang ditentukan itu ialab) bulan Ramadhan, bulan yang didalamnya diturunkan al-Qur'an sebagai petunjuk bagi manusia.........". (QS. Al-Baqarah [2]:185) 
a.s. diciptakan hingga penutup para Nabi, yaitu Rasulullah Saw ${ }^{2}$ yang dalam rentang waktu tersebut terdapat juga kisah tokoh-tokoh lain yang terkenal.

Ajaran-ajaran yang terkandung dalam al-Qur'an disampaikan secara variatif, seimbang dan selaras. Ketika al-Qur'an menguraikan tentang gambaran dan nikmat Syurga maka ayat selanjutnya menceritakan keganasan Neraka, begitu pula ketika bercerita tentang kebaikan, kemudian disambung dengan kejahatan dan hukumanya. Ayat-ayatnya juga dikemas sedemikian rupa, ada yang berupa informasi, perintah dan larangan, dan ada juga yang dimodifikasi dalam bentuk deskripsi kisahkisah yang mengandung ibroh dan nilai research. ${ }^{3}$ Sebagaimana yang tercantum dalam (QS. Yusuf [12]: 11)

Sebagai produk wahyu kisah dalam al-Qur'an tentu saja berbeda dengan cerita atau dongeng pada umumnya, karena perbedaan karakteristik yang terdapat dalam masing-masing kisah, ada yang menekankan aspek-aspek tertentu dari kehidupan mereka, hubungan antar sesama manusia, antar kelompok termasuk dalam

2 Tradisi kenabian secara efektif dimulai dari Ibrahim sebelum bercabang menjadi dua riwayat suci yang terpisah, yakni keturtunan Ishak dan Ismail. Riwayat keturunan Ishaq mengikuti jejak pergantian dari Bani Israil yang dianugerahi satu rangkaian patriarkal [tata kekeluargaan yang sangat mementingkan garis keturunan Bapak] yahudi -termasuk Musa, Daud dan Sulaiman -yang puncaknya pada kemunculan Isa al-Masih pada abad pertama Masehi. Sedangkan garis keturunan ismail berujung pada Muhammad, seorang utusan non yahudi yang berasal dari rakyat jelata. Kemunculan nabi berbangsa arab ini dipandang oleh umat islam sebagai peristiwa penting yang terakhir dalam sejarah suci tauhid. Shobbir Akhtar, Islam Agama Semua Zaman, (Jakarta: Pustaka Zahro, 2002), h. 15

${ }^{3}$ Tujuan utama dan pertama dari kisah al-Qur'an adalah sebagai ibrah yaitu untuk pelajaran. Oleh karena itu yang diutamakan dalam kisah bukan menjelaskan tempat dan tanggal kejadian. Apalagi bila ditinjau dari sudut universalitas al-Qur'an, maka makin terasa penyebutan tempat dan waktu tersebut secara eksplisit semakin tampak urgenya, akan lebih terasa bahwa petunjuk al-Qur'an ditujukan untuk semua orang dan pada semua tempat bukan bagi bangsa tertentu sebagaimana juga bukan bagi tempat tertentu. Kisah dalam al-Qur'an bisa dijadikan penyelidikan ilmiah (research). Dengan demikian akan lahir upaya yang kontinyu demi mencari kebenaran tentang peristiwa yang pernah terjadi dimasa lampau, juga untuk memberikan motivasi bagi para ilmuwan yang berminat terhadap sejarah dan kehidupan sosialnya untuk melakukan penelitian dan penyelidikan ilmiah. Nashrudin Baidan, Wawasan Baru Ilmu Tafsir, (Yogyakarta: Pustaka Pelajar, 2005), h. 244-245 
kaitan dengan pemimpin mereka, antara bangsa (seperti orang-orang yahudi dan orang-orang Mesir). ${ }^{4}$

Al-Qur'an meliputi cerita tentang para Nabi, pengikut mereka dan musuh-musuh mereka, saling berhubungnan, persaingan dan perkelahian antara pengikut dengan musuh. Semua ini memperluas waawasan dan pandangan sejarah yang bisa dipergunakan sebagai pelajaran dan memberi pedoman bagi umat manusia. Dalam hubungan ini, ayat al-Qur'an bisa bersifat normatif, tidak sekedar memberi informasi melainkan juga memberi instruksi, ${ }^{5}$ dengan melihat fenomena kisah-kisah dalam al-Qur'an yang banyak berkaitan dengan sejarah yang hampir semuanya bertujuan hendak memberikan suatu pengertian moral atau filosofis yang sifatnya universal.

Kisah-kisah ${ }^{6}$ yang dimuat dalam al-Qur'an semuanya cerita yang benar-benar terjadi, tidak ada cerita fiksi, khayal apalagi dongeng. Jadi bukan seperti ynag dituduhkan oleh sebagian kaum orientalis, bahwa dalam al-Qur'an ada kisah yang tidak cocok dengan fakta sejarah, ada pula yang mengatakan bahwa kisah tersebut adalah karangan Nabi Muhammad sendiri bukan turun dari Allah.

Untuk menepis tuduhan para Orientalis itu, al-Qur'an membantahnya dalam beberapa ayat ( QS. ali Imran [3]: 63), (QS. alKahfi [18]: 13), (QS. al-Qashash: 3)

Semua ayat diatas menjelaskan secara pasti bahwa semua kisah didalam al-Qur'an adalah benar, tak ada yang bohong atau mengada-ada dan sebagainya. Sebagian kisah sudah ada yang terbukti kebenaranya melalui penyelidikan ilmiah, ${ }^{7}$ dan ada sebagian yang

${ }^{4}$ Ahmad as-Shouwy.... [et. al], Mukjizat al-Qur'an dan as-Sunnah tentang IPTEK, (Jakarta: Gema Insani Press, 2001), h. 87

${ }^{5}$ Abdul Djalil, Ulumul Qur'an, (Surabaya: Dunia Ilmu, 2000), h. 95

${ }^{6}$ Apabila diamati kisah-kisah yang terdapat dalam al-Qur'an maka paling tidak akan ditemukan tiga kategori; Pertama, Kisah para Nabi, Mukjizat mereka, fase-fase dakwah mereka, dan penentang serta pengikut mereka. Contohnya, kisah Nabi Adam, Nuh, Ibrahim, Musa, Isa, Muhammad Saw dan lain-lain. Kedua, Kisah orang-orang yang belum tentu Nabi dan kelompok-kelompok manusia tertentu. Contohnya kisah Lukmanul Hakim, Qarun, Thaluth, Ashabul Kahfi, Ashabul Fill, dan lain-lain. Ketiga, Peristiwa-peristiwa dan kejadian kejaidian di zaman Rasul Saw. Contohnya kisah perang Badar, perang Uhud, Hunain, Tabuk, perang Ahzab, dan Isro’ Mi'roj Nabi Muhammad Saw. Abdul Djalil , Ulumul Qur'an, h. 300

${ }^{7}$ Menurut sejarah setelah tenggelamnya Fir'aun, mayatnya ditemukan terdampar di pantai lalu diambil dan dibalsem oleh orang Mesir dan sampai 
belum terbukti, hal ini dikarenakan masih terbatasnya kemampuan manusia.

Para penafsir banyak yang memahami kisah-kisah dalam alQur'an hanya dengan tinjaun sejarah, padahal al-Qur'an tidak bermaksud menjadikan unsur-unsur sejarah tersebut sebagai tujuan pokok. Unsur-unsur sejarah tadi hanya sekedar elemen yang digunakan untuk mengkonstruksi sejarah tadi. Tujuan utama kisahkisah itu diceritakan adalah agar pendengarnya menangakap esensi cerita itu yang penuh dengan nasehat, hikmah, pelajaran, bahkan ancaman dan kabar gembira.

Al-Qur'an tidak menceritakan kejadian dan peristiwa secara berurutan dan tidak pula memaparkan kisah itu secara panjang lebar. Kisah-kisah dalam al-Qur'an merupakan petikan-petikan dari sejarah sebagai pelajaran kepada umat manusia dan bagaimana seharusnya mereka bisa menarik manfaat dari peristiwa-peristiwa sejarah. ${ }^{8}$ Seperti kisah Musa dan Fir'aun yang diungkapkan berulang-ulang dibeberapa surat.

Fir'aun merupakan salah satu tokoh yang kisahnya diabadikan dalam al-Qur'an dan ini bukanlah sekedar informasi sebagaimana buku sejarah, tapi ia datang untuk menjelaskan pesan-pesan sejarah. Banyak sekali pelajaran yang dapat kita petik dari kisah Fira'un, disamping pelajaran yang bisa dijadikan dasar dalam membina individu, gambaran konversi keagamaan, ${ }^{9}$ didalamnya juga memuat banyak unsur yang melibatkan hubungan antara penguasa dengan para bawahanya, baik dari kalangan ulama', cendikiawannya maupun orang-orang kaya yang semuanya membentuk rantai dan hubungan simbiosis dalam sebuah komunitas yang dlalim.

Kalau kita perhatikan sebagian ayat-ayat yang mengisahakan tentang Fir'aun selalu disebut bersama Musa a.s., al-Qur'an ingin menghadirkan mereka sebagai representasi dari dua kekuatan

sekarang jasadnya yang berupa mumi masih dapat kita lihat di museum Mesir. Bukti lain misalnya kisah Nabi Ibrahim bersama putranya Ismail membangun Ka'bah seperti diceritakan dalam Q.S. al-Baqarah [2]:127; dan sampai sekarang Ka'bah tersebut masih berdiri dengan megah di Makkah.

${ }^{8}$ Muhammad Chirzin, Permata al-Qur'an, (Yogyakarta: Qirtas, 2003), h. 58

${ }^{9}$ Muhammad al-Ghazali, Berdialog Dengan Al-Quran-Memahami Pesan Suci Dalam Kebidupan Masa Kini, (Bandung: Mizan, 1999), h. 77 
antagonistic yang tidak bisa dipisahkan, ini menunjukan bahwa pembahasan masalah Fir'aun tidak akan bisa utuh tanpa membahas sosok Musa a.s. yang mengemban dua misi, disamping sebagai seorang utusan (penerima wahyu) juga mengemban misi sosial yang memerdekakan, membebaskan kaum lemah dari cengkeraman penguasa Fir'aun yang dlalim.

Fir'aun dan para pengikutnya diberi nikmat berupa kekuasaan, intelektualitas dan kekayaan materi yang berlimpah tetapi mereka semua selalu mengingkari nikmat-Nya, tidak menjalankan apa yang diperintahkan Allah tetapi justru menjalankan apa yang dilarang dalam ajaran-ajaran-Nya, sehingga komunitas mereka sebagai bangsa yang diabadikan dalam al-Qur'an dihancurkan dan ditenggelamkan ke dalam Laut merah melalui Musa a.s.

Itulah konsep al-Qur'an mengenai hukuman sejarah yang akan ditimpakan kepada masyarakat atau bangsa, bukan kepada individu (mereka ini secara khusus akan dihukum dihari kiamat) yang telah melakukan dosa secara kolektif. ${ }^{10}$ Kebudayaan bangsa-bangsa tersebut akan dihancurkan dan ini adalah konsekuensi nasib yang harus diterima, karena al-Qur'an telah berulang kali menyerukan agar bangsa-bangsa didunia ini menarik manfaat dari pengalaman dan kekeliruan bangsabangsa terdahulu ${ }^{11}$

Selama ini pemahaman kita mengenai kisah Fir'aun bersifat ahistoris (tekstual), padahal maksud al-Qur'an menceritakan kisah itu adalah justru agar kita bisa berpikir historis (konstekstual). Pemahaman kita terhadap kisah tersebut selama ini hanya sebatas konteks zaman itu. Kita tidak pernah berpikir bahwa yang disebut penindas dan kaum tertindas itu sebenarnya ada disepanjang zaman dan disetiap sistem sosial, dulu, sekarang sampai peradaban yang akan datang. Oleh karena itu ayat-ayat tentang Fir'aun tidak bisa disikapi secara teks, Fir'aun sendiri adalah penguasa yang diktator, dibutuhkan interpretasi teks secara terbuka dan konstekstual untuk menemukan ide moral yang terkandung didalamnya sebagai alat introspeksi baik secara personal maupun dalam tatanan masyarakat global agar bisa terbebas dari struktur sosial yang tidak ramah, menindas,

${ }^{10}$ Fazlur Rahman, Tema Pokok al-Quran, (Bandung: Penerbit Pustaka, 1990), h. 77

${ }^{11}$ Ibid., h. xiii 
diskriminatif, eksploitatif menuju tatanan sosial yang lebih manusiawi, humanis dan bermoral.

Berdasarkan uraian singkat latar belakang diatas, cukup menarik untuk mengetahui lebih jauh gambaran Fir'aun dalam sejarah yang dikisahkan kembali lewat teks-teks al-Qur'an. Untuk menjawab permasalahan ini, perlu adanya rumusan masalah sebagai berikut: 1). Siapakah sebenarnya Fir'aun dan para pengikutnya yang di maksud dalam al-Qur'an, sehingga dihancurkan oleh Allah. 2). Seberapa jauh usaha atau campur tangan Nabi Musa a.s. dalam mengajak Fir'aun dan pengikutnya agar mereka mau menyembah kepada Allah SWT dan dalam membebaskan kaum tertindas dari belenggu perbudakan. 3). Mungkinkah muncul fenomena Fir'aun dan orang-orang tertindas pada masa sekarang dan akan datang.

\section{B. Kajian Teori}

Sebelum membahas lebih lanjut tentang Historisitas Kisah Fir'aun dalam Perspektif al-Qur'an, ada beberapa istilah yang perlu dijelaskan agar mudah dimengerti dan dipahami. Adapun istilah yang dimaksud adalah:

1. Fir'aun

Fir'aun ${ }^{12}$ adalah salah satu raja dlalim yang mati tenggelam di laut Merah, karena mengejar Musa dan Bani Israil tetapi jasadnya terselamatkan untuk dijadikan bukti kebenaran kisahnya. Fir'aun banyak melakukan berbagai bentuk penindasan terhadap Bani Israil. Sebagai utusan Allah Musa membela kaum yang lemah dan tertindas.

Ada perbedaan pendapat tentang siapakah sebenarnya nama asli sosok fenomenal Fir'aun yang hidup pada zaman nabi Musa. ${ }^{13}$

${ }^{12}$ Kata dalam bahasa Ibrani untuk menyebut Raja-raja Mesir kuno. Lihat Ensiklopedi Umum, (Jakarta: Penerbit Yayasan Kanisius, 1973), h. 236. Kata ini diperkirakan berasal dari bahasa Ibrani Per-O yang artinya rumah besar, gelar ini diterapkan secara turun temurun kepada raja-raja Mesir kuno. Karena mereka dianggap sebagai titisan dewa-dewa negeri Mesir, seperti; Horus, Buto, dan lainlainya. Ensiklopedi Umum, Harun Nasution.....[et, al, (Jakarta: Anggota IKAPI, 1992), h. 250

${ }^{13}$ Mengenai siapakah sebenarnya Fira'un pada zaman Nabi Musa akan penulis jelaskan pada Bab II 


\section{Perspektif}

Cara melukiskan suatu benda dan lain-lain pada permukaan mendatar sebagaimana yang terlihat oleh mata dengan tiga dimensi (panjang lebar dan tingginya). Sudut pandangan. ${ }^{14}$

\section{Al-Qur'an}

Al-Qur'an ${ }^{15}$ Merupakan kitab suci umat islam yang ketika diturunkan berupa teks non bahasa pada taraf vertikalnya (AllahJibri), tetapi teks tersebut menjadi teks yang berbahasa pada taraf Horizontal (Jibril-Muhammad) ${ }^{16}$ selama kira-kira 22 tahun. Sementara ulama merinci 22 tahun, 2 bulan, 22 hari.

${ }^{14}$ Kamus Besar Bahasa Indonesia, Departemen Pendidikan dan Kebudayaan, (Jakarta: Balai Pustaka, 1990), h. 675

${ }^{15}$ Kata al-Qur'an menurut pengertian bahasa arab adalah Mashdar dari kata Qara'a, Yaqra'u, Qira'atan, Qur'anan; yang berarti bacaan. Tapi imam syafi'i dan imam Suyuthi berpendapat bahwa al-Qur'an secara bahasa bukanlah merupakan kata bentukan dari kata qara'a seperti penjelasan sebelumnya. Menurut mereka alQur'an merupakan suatu nama ('alam) bagi kitab allah yang diturunkan kepada nabi Muhammad, sama halnya dengan kitab-kitab lain seperti Taurat dan Injil. Jadi menurut mereka kata al-Qur'an itu bukanlah berarti bacaan, melainkan nama bagi suatu kitab Allah SWTT.

Banyak definisi Syar'i tentang al-Qur'an yang diberikan oleh para Ulama'. Sebagian mereka ada yangh memberikan definisi secara panjang lebar dan yang lainya memberi definisi yang sangat ringkas, salah satu definisi yang serba mencakup adalah apa yang dikemukakan oleh Muhammad Ali al-Hasan:

Artinya: "Al-Qur'an adalah kalamullah yang bersifat mukjizat yang diturunkan kepad anabi $S A W$ yang dinukuil secara tawatur dan membacanya tergolong ibadah". Lihat. Muhammad Rahmat Kurnia, Muhammad Sigit Purnawan Jati, Muhammad Ismail Yusanto, Prinsip-prinsip Pemahaman al-Qur'an dan Hadits, (Jakarta: Khairul Bayan, 2002), h. 1-2

${ }^{16}$ Terdapat banyak perbedaan pendapat mengenai medium bahasa dalam proses komunikasi wahyu, bagaimana proses komunikasi wahyu ini dapat terjadi padahal terdapat perbedaan watak karena perbedaan tingkat eksistensinya. Lihat. Nasr Hamid Abu Zaid, Tekstualitas Al-Qur'an-kritik terbadap Ulumul Qur'an, (Yogyakarta: Lkis, 2001), h. 34-36. Bandingkan dengan pendapatnya Muhammad Abduh, Rifat Syauqie Nawawi. Lihat. Mohammad Nor Ichwan, Belajar Mudah Ilmuilmu al-Qur'an, (Seri Buku Daras Ulum Al-Qur'an. 2001), h. 1-21 


\section{Analisis Kisah Fir'aun Dengan Pendekatan Historis
a. Urgensi Kajian Historis Dalam Memahami Kisah-kisah al-Qur'an

Meskipun ayat-ayat al-Qur'an yang menceritakan Fira'un tergolong banyak, namun tidak diceritakan secara kronologis, sehingga sangat menyulitkan para mufasir untuk menjelaskan maknanya secara utuh. Cerita tentang Fir'aun, sepak terjang dia yang selalu menindas dan berbuat sewenang-wenang, kufur nikmat, kufur secara akidah tauhid dengan mengaku sebagai tuhan, secara sekilas terkesan diulang-ulang, padahal style atau gaya bahasanya berbeda beda yang tentu saja aspek penekanannya juga berbeda-beda. Lebih parah lagi jika kita memaknai kisah-kisah dalam al-Qur'an tentang nasib umat-umat terdahulu termasuk didalamnya Fir'aun dipahami hanya sebatas teks saja, sehingga mengaburkan makna yang terkandung didalamnya.

Ada beberapa permasalahan yang sangat signifikan dalam memahami kisah-kisah dalam al-Qur'an, antara lain:

a. Para penafsir banyak yang terjebak dalam mempelajari kisahkisah al-Qur'an. Hal ini disebabkan, mereka memahami kisahkisah al-Qur'an tersebut sebagaimana mereka membaca teksteks sejarah. Padahal yang lazim digunakan untuk menangkap pesan-pesan dari kisah-kisah al-Qur'an adalah dengan membacanya sebagai teks-teks keagamaan dan teks-teks sastra yang memiliki keindahan dan keistimewaan tersendiri.

b. Kesatuan kisah yang diangkat dalam al-Qur'an banyak memuat dan menonjolkan materi-materi keagamaan dan pesan-pesan khusus yang tersirat dalam kisah tersebut, seperti pesan-pesan sosial dan moral.

c. Al-Qur'an jarang sekali menampilkan kisah-kisah yang berhubungan dengan unsur-unsur kejadian sejarah tertentu. Justru al-Qur'an sering dengan sengaja menyembunyikan unsur-unsur sejarah dari suatu kisah baik itu waktu atau tempat. ${ }^{17}$

${ }^{17}$ M. Ahmad Khalafullah, al-Qur'an Bukan Kitab Sejarab - Seni, Sastra, dan Moralitas dalam Kisab-kisah al-Qur'an, terj. Zuhairi Misrawi dan Anis Maftukhin, (Jakarta: Paramadina, 2002), h. 15 
Untuk mendapatkan pemahaman tentang makna kisah Fir'aun secara komprehensif harus melalui kajian historis-kontekstual, dalam konteks apa dan bagaimana ayat tersebut diturunkan. Oleh karena itu, memahami kisah Fir'aun tidak bisa berhenti pada teksnya saja. Selama ini pemahamam kita tentang kisah-kisah dalam al-Qur'an cenderung bersifat ahistoris (tekstual), padahal maksud al-Qur'an menceritakan kisah itu adalah agar kita bisa berpikir historis (kontekstual).

Pendekatan kontekstual seperti diterangakan oleh Djohan Effendi, adalah metode pemahaman yang bersifat sosio-bistoris, yakni mendekati suatu gagasan atau fenomena tidak lepas dari konteks waktu, tempat kelompok dan lingkungan yang sedikit banyak ada hubunganya dengan sebab turunya ayat tersebut. ${ }^{18}$ kisah mengenai umat-umat terdahulu sudah sangat komplit dan bervariasi, mereka semua mengingkari Nabi-nabinya sebagai akibatnya mereka dihancurkan Allah dengan peristiwa bencana Alam. Karena semua cerita ini merupakan sarana pengajaran dan pemberi pelajaran, maka bukanlah muatan sejarah, tapi pesan moral yang ingin disampaikan oleh al-Qur'an. ${ }^{19}$

Al-Qur'an sudah memerintahkan kepada kita agar mengaitkan kejadian masa kini dengan masa lampau dengan tujuan memproyeksikan peristiwa kekinian pada struktur yang universal. ${ }^{20}$ Bahkan hampir $1 / 3$ kandungan al-Qur'an berisi pesan-pesan Historis. ${ }^{21}$

\section{b. Fir'aun Dan Kehancuranya}

Fir'aun dalam al-Qur'an digambarkan sebagai sosok penguasa yang zhalim, walaupun dalam sejarah banyak terjadi perbedaan pendapat mengenai siapakah sebenarnya Fir'aun yang dikisahkan hidup pada zaman Nabi Musa, melalui bukti-bukti dan temuantemuan yang dilakukan oleh beberapa ahli Egyptologi secara pasti memang dapat ditentukan bahwa Ramses II dan Marneptah-lah yang hlm.276.

${ }^{18}$ Rosihun Anwar, Samudra al-Qur'an (Bandung: Pustaka Setia, 2001),

${ }^{19}$ Fazlurrahman, W.C. Smith.....[et-al], Agama untuk Manusia (Yogyakarta: Pustaka Pelajar, 2000), h. 18.

${ }^{20}$ (QS. al-Qamar [54]: 41).

${ }^{21}$ TH. Thalhas, Hasan Basri, Spektrum Saintifika al-Qur'an, Jakarta: Bale Kajian Tafsir al-Qur'an Pase, 2001), h. 43. 
hidup pada masa Nabi Musa. Atau ada yang berpendapat nama Fir'aun yang hidup sezaman dengan Nabi Musa a.s. adalah Al-Walid ibnu Mus'ab ibnu Rayyan, atau Mus'ab ibnu Rayyan, yang mempunyai nama kun-yah Abu Murrah.

Terlepas dari semua itu, Al-Qur'an secara sengaja menyembunyikan nama-nama Fir'aun tersebut (begitu juga bible tidak menyebutkan nama Raja Mesir itu), karena maksud al-Qur'an menceritakan kisah Fir'aun bukan untuk membentuk kronologi cerita yang didalamnya memuat unsur-unsur seperti nama, tempat dan lainlain. Al-Qur'an bahkan tidak menyebutkan nama-nama tempat, yaitu kota yang dibangun oleh orang Israil pengikut Musa ataupun tidak menyebutkan matinya Fir'aun ketika Musa menetap di Madyan.

Tetapi al-Qur'an secara panjang lebar menguraikan beberapa karakter dan bentuk-bentuk penindasan Fir'aun terhadap orangorang Israil pengikut Musa. Antara lain Fir'aun digambarkan sebagai pengausa yang sangat zhalim yang berbuat melebihi kodaratnya sebagai manusia (Innahu Thagha). Dan bertindak tidak manusawi dengan memperbudak rakyat yang lemah. Ia telah mengigkari jati dirinya sebagai hamba dan berpretensi sebagai tuhan.

Pembangakangan yang dilakaukan oleh Fir'aun dan para pendukungnya antara lain, penyembelihan anak laki-laki (QS. alBaqarah [2]:49), Kezhaliman (QS. Al-'araf [7]:103), penganiayaan terhadap rakyat (QS. Al-'Araf [7]: 141), kesombongan diri (QS. Yunus [10]: 75), pemborosan (Lihat misalnya Monumen-monumen megahnya yang mereka dirikan tanpa makna ekonomis), pemerintahan sewenang-wenang (QS. Thaaha [20]: 43), kebijakan memecah belah kelompak masyarakat untuk melayani kepentingan serta perusakan (QS. Al-Qashash [28]: 4), berbagai kesalahan dan kriminal (QS. Al-Qashash [28]: 8), dan lain-lain.

Banyak sekali nikmat yang telah Allah berikan kepada Fir'aun tetapi ia dan para pengikutnya selalu kufur. Oleh karena itu Musa diutus kepada Fir'aun agar mau menyembah Allah. Disamping kesombongan Fir'aun dan Haman yang telah dijelaskan al-Qur'an, masih banyak profil hamba-hamba Allah SW'T yang durhaka, 
diantaranya Qorun. ${ }^{22}$ Allah SWT mengutus Nabi Musa a.s. untuk mengajak Qarun agar berbuat kebaikan, dan kembali ke jalan allah.

Artinya: "dan (juga) Karun, Fir'aun dan Haman. Dan sesunggubnya telah datang kepada mereka Musa a.s. dengan (membawa buktibukti) keterangan-keterangan yang nyata. Akan tetapi mereka berlaku sombong di (muka) bumi, dan tiadalab mereka orangorang yang luput (dari kehancuran)". (QS.al-Ankabut :39)

Dalam ayat diatas Allah mengkatagorikan Qarun seperti Fir'aun. Sebagaimana juga Haman. Kategori yang dimaksud adalah keduanya punya karakter yang suka menindas terhadap rakyat miskin, dan samasama mendustakan utusan Allah dan menolak perintah ini dengan mengatakan bahwa Musa hanya seorang ahli sihir yang dusta. Disamping kesombongan Fir'aun dan Haman yang telah dijelaskan al-Qur'an, masih banyak profil hamba-hamba Allah SWT yang durhaka, diantaranya Qorun.

Penyebutan Qarun bersama Fir'aun dalam satu teks itu, semakin menegaskan bahwa karakter-karakter Fir'aun akan selau muncul dalam realitas sosial. Peran Musa kepada Fir'aun - yang karakteristiknya telah diwarisi oleh pengikut-pengikutnya yang lain adalah pada soal ilusi kekuasaan dan keabadianya yang telah memperbudak dirinya dan para pengikutnya. Karena universalitas perhatian tuhan maka kesempatan harus slalu diberikan kepada setiap hambanya agar mau kembali kejalan yang benar dengan diberikanya peringatan-peringatan yang berupa munculnya wabah penyakit, tahun-tahun kekeringan, dan lain-lain.

Tapi ketika peringatan-peringatan sudah tidak bisa mengubah karakter manusia, seperti Fir'aun maka azab didunia akan menjadi hukuman bagi mereka yang membangkang.

${ }^{22}$ Dalam sejarah dikisahkan bahwa Qarun adalah seorang yang sangat kaya raya dari Bani Israil. Allah SW'T telah memberikan kekayaan yang sangat banyak, sehingga kalau anak kunci gudang-gudang tempat menumpuk harta itu dikumpulkan semuanya, maka tidak ada seorangpun yang bagaimana juga kuatnya dapat memikul anak-anak kunci itu. Dengan harta benda yang dimilikinya itu, dia bukan menolong memperbaiki nasib orang-oarng miskin tapi malah memperbudak mereka serta memeras tenaganya. Lihat S. M. Suhufi, Kisah-kisah dalam al-Qur'an, terj. Alwiyah Abdurrahman, (Bandung: Penerbit al-Bayan, 1994), h. 110. 
Artinya: "(keadaan mereka) serupa dengan keadaan Fir'aun dan pengikutpengikutnya serta orang-orang yang sebelumnya. Mereka mendustakan ayat-ayat Tubannya maka Kami membinasakan mereka disebabkan dosa-dosanya dan Kami tenggelamkan Fir'aun dan pengikutpengikutnya; dan kesemuanya adalah orang-orang yang zalim”. QS. al-Anfal [8:54]

Akhirnya karena kesombonganya itu, maka Fir'aun dan para pengikutnya (Qarun dan Haman) diazab oleh Allah SWT. Fir'aun ditenggelamkan di laut merah, sedang Qarun beserta kekayaanya termasuk rumahnya dibenamkan kedalam bumi. Itulah medan sejarah yang harus diterapkan pada masa sekarang ini, terlepas dari Fir'aun yang hidup pada masa Nabi Musa, atau orang-orang yang durhaka kepada Allah pada zaman setelahnya, baik itu setelah Nabi Isa atau setelah Rasul terakhir yaitu Muhammad SAW. Ibrah dari kehancuran Fir'aun adalah ketika manusia sudah melampaui batas zhalim, menindas dan melupakan prinsip-prinsip risalah tuhan yang disampaikan melalui utusanya, maka azab Allah pasti terjadi dalam segala bentuk.

Gambaran diatas mengingatkan dan sekaligus menyadarkan kita untuk mentaati hukum Allah, dan mengajak kita untuk merenungi kembali makna yang terkandung dalam kitab suci alQur'an, terutama pengungkapan kisah-kisahnya yang banyak mengandung nilai-nilai untuk dijadikan bahan introspeksi baik secara personal maupun secara luas dalam bermasyarakat dan bernegara. Kehancuran Fir'aun merupakan ilustrasi Allah dalam menumpas segala kejahatan dan kezaliman, maka tidak mustahil diabad ini peristiwa yang sama akan terulang lagi jika umat

ini lalai dari kewajibanya.

Oleh karena itu ancaman Allah untuk menghancurkan suatu negara, bangsa, dan masyarakat, disangkutkan dengan kedzaliman sosial. Masyarakat yang tidak mewujudkan keadilan akan dihancurkan oleh Allah tanpa peduli apakah masyarakat itu secara formal menganut ajaran yang benar atau tidak. ${ }^{23}$ seperti Fir'aun dan umatumat sebelumnya.

${ }^{23}$ Lihat (QS. al-Isra' [17]: 16); dan (QS. Muhammad [47]: 38). 
Artinya: "Telah mendustakan (rasul-rasul pula) sebelum mereka itu kaum Nub, 'Aad, Fir'aun yang mempunyai tentara yang banyak, dan Tsamud, kaum Luth dan penduduk. Aikah. Mereka itulah golongangolongan yang bersekutu (menentang rasul-rasul). Semua mereka itu tidak lain hanyalah mendustakan rasul-rasul, maka pastilah (bagi mereka) azab-Ku". QS. Shaad [38:12-14]

Artinya: "Sebelum mereka telab mendustakan (pula) kaum Nub dan penduduk Rass dan Tamed. dan kaum Aad, Kaum Fir'aun dan kaum Luth, dan penduduk. Aikeah serta kaum Tubba' semuanya telah mendustakan rasul-rasul maka sudah semestinyalah mereka mendapat bukuman yang sudah diancamkan”. QS. Qaf [50:12-14]

Ayat diatas merupakan Sunnatullah tuhan sekaligus sebagai peringatan terhadap manusia bahwa kaum yang sombong, durhaka seperti; Kaum Nuh, ${ }^{24}$ 'Ad, ${ }^{25}$ Fir'aun, Tsamud, ${ }^{26}$ kaum Luth, ${ }^{27}$ Ashabul Aikah, ${ }^{28}$ Ashabur Rass ${ }^{29}$ akan dihancurkan oleh Allah.

${ }^{24}$ Dalam al-Qur'an Kaum Nuh sering dirujuk sebagai kaum yang telah dimusnahkan lantaran tidak beriman. Nuh diutus sebagai Rasul untuk kaumnya, dan mereka kafir serta ditenggelamkan lewat banjir, bahkan anaknya Kan'an ikut tenggelam, sementara Nuh dan orang-orangnya yang beriman diselamatkan dalam bahtera, lih. (QS. Hud [11]: 25-48).

25 'Ad merupakan kaum zaman lampau yang tinggi besar, mungkin berbentuk raksasa, Lihat. (QS. al-A'raf [7]: 69); yang membangun "tanda-tanda" diatas Bukit tinggi, lih. (QS. asy- Syu'ara [26]: 128). Rasul Hud diutus kepada mereka, tetapi mereka mengingkarinya dan dimusnahkan oleh angin yang membadai selama tujuh hari tujuh malam dan menyapu bersih segala sesuatu kecuali bangunan yang telah dibuatnya.

26Dikatakan bahwa mereka telah membor batu-batu karang di Wadi, lih. (QS. al-Fajr [89]: 9); membangun istana ditempat-tempat yang datar dan memahat gunung untuk membangun rumah, lih. (QS. al-AAraf[7]: 74). Reruntuhan bangunan mereka masih dapat disaksikan lih. (QS. An-Naml [27]: 52), dan (QS. al-Ankabut [29]: 38). Seorang Rosul diutus kepada mereka, dan sebagai bukti kebenaran pesan ilahi yang dibawanya adalah seekor unta betina dan seekor kuda yang menghasilkan mukjizat, kedua binatang ini harus dihormati dan diberi minum. Namun kaum Tsamud mengingkari dan memotong-motong unta tersebut. Mereka lalu dimusnahkan oleh gempa bumi, lih. (QS. al-'Araf[7]: 78); oleh azab petir, (QS. Fushilat [41]: 16); dan (QS. adz- Dzariyat[51]: 44); atau oleh suatu "teriakan keras" yang dikirim kepada mereka, (QS. al- Qamar[54]: 31).

${ }^{27}$ Luth telah diutus kepada kaumnya. Ia mempersalahkan mereka karena ketidaksenonohan dan praktek sodomi (homoseksual), ketika menentangnya dan mengancam akan mengusirnya, ia dan keluarganya diselamatkan (kecuali istrinya 
Jenazah Fir'aun yang mati tenggelam diselamatkan oleh Allah agar dijadikan pelajaran, dengan menimbang, mengenalinya, memikirkanya, dan menjadikanya sebagai nasihat.

Artinya: "Maka pada hari ini Kami selamatkan badanmu supaya kamu dapat menjadi pelajaran bagi orang-orang yang dating sesudahmu dan sesunggubnya kebanyakan dari manusia lengah dari tanda-tanda kekuasaan Kami.” QS. Yunus [10:92]

Masa kekuasaan Fir'aun telah ribuan tahun berlalu, pada saat turunya ayat ini, sejarah sudah tidak mengetahi dimana tubuh Fir'aun, namun dengan kehendak Allah mayat Fir'aun tidak tenggelam kedasar laut tetapi ombak menyelamatkan jasadnya dan menghempaskanya ke tepi pantai dan akhirnya penemuan Mumi menyingkapkan ayat tersebut. Satu ayat yang meramalkan peristiwa ribuan tahun yang lalu kemudian baru terjadi. Dan ini merupakan tanda-tanda dari Allah agar dijadikan pelajaran bagi orang-orang yang datang kemudian.

\section{c. Moral Pembebasan}

Al-Qur'an banyak menceritakan kisah-kisah para Nabi, ini merupakan titik sentral yang sangat penting sebagai pelajaran tentang sifat-sifat Allah SW'T yang sepesifik seperti pengasih, pengampun, berkuasa dan memberikan hukuman.

Kisah Musa dan Fir'aun tidak mengungkapkan sesuatu yang baru secara esensial, tetapi menghadiran kebenaran akan janji-janji Allah SWT terhadap kaum yang bersabar dalam menghadapi cobaan dan tertindas akan diberi nikmat dan kaum yang sombong akan di azab di diunia maupun di akhirat. Janji-janji Allah ini nyata ketika Musa a.s. diutus oleh Allah sebagai nabi revolusioner yang membawa misi pembebasan melawan otoritarianisme dan sistem pemerintahan

yang 'tertinggal'). Kota kaum Luth lalu dimusnahkan oleh suatu hujan besar yang dikirim diatasnya, atau oleh badai yang menyeramkan, lih. (QS. al-Qamar[54]: 34).

${ }^{28}$ Ashabul Ayka (orang-orang dari Hutan atau belukar) yang dirujuk dalam (QS. al- Hijr[15]: 78; 38:13 dan QS. Qaaf [50]: 14), identik dengan kaum Madyan, karena Rasul mereka adalah Syuaib, mereka juga diseru untuk menyempurnakan takaran dan timbangan secara adil. Seperti orang-orang kafir lainya, kaum Madyan juga dimusnahkan dengan gempa bumi, atau teriakan mengguntur.

${ }^{29}$ Orang-orang al-Rass dirujuk dalam daftar kaum-kaum kafir yang dimusnahkan, tetapi tidak diberikan penjelasan apapun tentang mereka, lih. (QS. alFurqan [25]: 38); dan (QS. al-Qaaf [50]: 123). 
dalam tatanan sosial yang korup dan zhalim pada masa Fir'aun, misimisi revolusioner serupa juga diemban oleh nabi-nabi yang lain. ${ }^{30}$

Pesan lain yang dapat kita tarik dari kisah Fir'aun adalah tentang ketertindasan Bangsa Israil. Bani Israil sebagai orang jelata atau Masyarakat awam, disebut oleh al-Qur'an dengan Mustadl'afin (lemah dan tertidas).

Teks yang merujuk pada Mustadl'afin fil ardh muncul pada awal QS. Al-Qashash, surat yang pokoknya berkisah tentang keluarnya Bani Israil karena ditindas oleh Fir'aun dan kelas penguasa Mesir. Islam secara tegas memandang penting kaum lemah sebagai status sosial yang tertindas untuk dijadikan pemimpin dan pewaris bumi.

Sebagaimana dalam QS. al-Qashash [28]:5

Artinya: "Dan Kami hendak memberi karunia kepada orang-orang yang tertindas di bumi (Mesir) itu dan bendak menjadikan mereka pemimpin dan menjadikan mereka orang-orangyang mewarisi (bumi)"

Ayat ini merupakan penggalan dari rangkaian panjang yang menceritakan kisah Fir'aun sebagai representasi penguasa otoriter, dictator eksploitatif, dan menindas serta Nabi Musa dan kaumnya Bani Israil, sebagai representasi kaum lemah dan tertindas.

Istilah Mustadl'afin didalam teks ini dirasakan berlaku bagi semua orang tertindas diseluruh dunia, tanpa melihat latar belakang agamanya, Allah memberi posisi utama dan lebih jauh janji pembebasan tetap ada walaupun dalam ketiadaan iman kepada tuhan.

${ }^{30}$ Ibrahim merupakan cermin revolusi akal menundukan tradisi-tradisi buta, revolusi tauhid melawan berhala-berhala, Isa tampil sebagai pembela orangorang papa yang berjuang menentang para pendeta yahudi dan saudagar yang telah bersekutu dengan penakluk Roma juga merupakan contoh revolusi roh atas dominasi materialisme, dan Muhammad merupakan teladan kaum papa, hamba sahaya, dan komunitas tertindas yang berhadapan dengan para konglomerat elit Quraisy dan gembong-gembongnya dalam perjuangan menegakan masyarakat yang bebas, penuh kasih sayang, persaudaraan dan egaliter. Banyak cerita-cerita tentang Nabi yang secara esensial menghadirkan pembebasan dalam risalah-risalahnya. Hud menentang mereka yang mendirikan pada tiap-tiap tanah bangunan tinggi untuk bermain-main dan benteng-benteng demi kekalnya hidup mereka didunia, lih. (QS. as-Syu'ara [26]: 128); Shaleh memupuskan harapan orang-orang kaya dengan menolak masuk kedalam sistem nilai mereka, lih. (QS. Hud [11]: 62); Yusuf menolak pelecehan seksual dari Zulaikah yang kaya dan berkuasa dan menderita karena penolakan itu, lihat. (QS. Yusuf [12]: 23-30). 
Ini adalah contoh solideritas tuhan yang tak terbatas dan tak pilihpilih dengan mereka yang tersisih, tertindas dan diperbudak.

Teks diatas harus ditafsiri dengan landasan gagasan tentang keutamaan posisi kaum tertindas dengan membawa ruh dasar alQur'an kedalam kehidupan, serta harus didekati lewat keputusan sadar untuk menemukan makna yang memberi tanggapan secara kreatif pada penderitaan Mustadl'afin dan berpegang teguh pada pembebasan dan keadilan. Sehingga kontekstualitas dari ayat diatas bisa muncul karena sesungguhnya teks itu berbicara mengenai realitas sosial yang selalu ada pada masa sekarang atupun masa yang akan datang yang tidak jauh berbeda dengan kondisi ketertindasan Bani Israil pada masa Fir'aun.

Al-Qur'an dengan jelas dan tanpa ragu-ragu berdiri dipihak masyarakat lemah dalam menghadapi para penindas, al-Qur'an menyesalkan bahkan menegur orang-orang yang tidak mau menolong mereka yang teraniaya. ${ }^{31}$

Teologi Qur'ani tidak hanya dengan keras mengecam eksploitasi, arogansi kekuasaan dan penindasan, namun juga memerintahkan kepada orang-orang ynag beriman untuk memerangi orang-orang jahat dan untuk menyelamatkan golongan yang lemah dan tertindas. Salah satu dari sejumlah doktrin ajaran fundamental dalam islam adalah prinsip-prinsip persamaan atau kesetaraan dan keadilan yang merupakan tema populisme atau pembebasan dan pembelaan terhadap kaum lemah, rakyat kecil dan tertindas. ${ }^{32}$ Oleh karena itu islam sesungguhnya merupakan agama kaum mustadl'afin yang sesuai dengan cita-cita al-Qur'an seperti disebutkan oleh Fazlurrahman, yaitu menegakkan tata sosial yang etis (berlandaskan Moral), ${ }^{33}$ egalitarian, dan berkeadilan, ${ }^{34}$ atau sejalan dengan dasar

${ }^{31}$ Lih. QS. al-Nisa' [4]: 75.

32 Hendar Riyadi, Tafsir Emansipatoris-Arah Baru Studi Tafsir al-Qur'an (Bandung: Pustaka Ceria, 2005), h. 43.

${ }^{33}$ Islam sangat memperhatikan aspek sosial disamping aspek ritual. AlQur'an misalnya; membuat kriteria orang yang bertaqwa, disamping beriman kepada yang Ghaib (Tuhan), kitab-kitab, hari akhir, dan mendirikan Shalat (aspek Religiusitas), juga menginfakan sebagian harta kekayaanya untuk kepentingan sosial, al-Qur'an juga menggambarkan bahwa orang yang bertaqwa adalah yang beriaman kepada Allah, hari akhir, kitab-kitab, dan beriman kepada para nabi, mendirikan Shalat (aspek religiusitas), juga mau memberi harta yang dicintai kepada kerabatnya, anak-anak yatim, orang-orang miskin, musafir yang memerlukan pertolongan dan 
tujuan islam seperti dikemukakan oleh Asghar Ali Engineer, yaitu terciptanya persaudaraan universal (universal Brotherhood), kesetaraan (Equality), dan keadilan sosial (Social Justice). ${ }^{35}$

Dalam pandangan kosmologi al-Qur'an, konsep keadilan menyangkut pandangan tentang hukum keseimbangan (mizan) yang menguasai jagad raya. ${ }^{36}$ Dengan demikian melanggar keadilan termasuk perbuatan dzalim, yaitu sebuah dosa kosmis, dosa yang amat berat dan bukan sekedar dosa pribadi.

\section{d. Fir'aun Dalam Konteks Ke-Indonesiaan}

Dewasa ini telah muncul gejala thaghut dimana-mana, segala sesuatu yang merupakan objek pemujaan, ketaatan tanpa batas dan pengabdian; seperti negara, perusahaan, atau tokoh kharismatik dapat disebur sebagai thaghut.

Suatu umat yang didominasi oleh penguasa yang zholim dan sewenang-wenang adalah umat yang tidak diharapkan untuk hidup, berkembang dan berbudaya.

Al-Qur'ân secara pararel nasib bangsa-bangsa yang tidak mau menerima bahkan menolak dengan beragam intimidasi dan ancaman pembunuhan terhadap rasul-rasul yang diutusnya. Ada dua karakter yang dimunculkan dalam kisah-kisah tadi; yaitu kelas penindas dan tertindas yang selalu ada di segala zaman, baik masyarakatnya taat kepada Allah atau dalam sebuah komunitas yang masih menganut ajaran agama-agama bumi.

Indonesia adalah sebuah negara yang mayoritas masyarakatnya beragama islam, tapi dalam kenyatanya tidak semua masyarakatnya menjalankan ajaran dengan sempurna. yang hampir rata-rata bisa menempati posisi penting dalam pemerintahan yang dari mulutnya kebijakan-kebijakan bisa muncul, ironisnya kebijakan

orang yang meminta-minta, (memerdekakan) hamba sahaya, menunaikan zakat, menepati janji, serta bersabar dalam kesempitan, penderitaan dan dalam peperangan (aspek sosial).

34 Fazlurrahman, Tema Pokok al-Qur'an, terj. Anas Mahyuddin, (Bandung: Pustaka, 1993), h. 54-55.

${ }^{35}$ Asghar Ali Engineer, Islam dan Theologi Pembebasan, terj. Agung Prihantoro, (Yogyakarta: Pustaka Pelajar, 2000), h. 33.

${ }^{36}$ (QS. ar-Rahman [55]: 7-9). 
itu selalu memihak pada kalangan atas. Hal ini bisa kita lihat pada pemerintahan suharto.

Ada beberapa penguasa di negeri ini yang dzalim, otoriter, berbuat sewenang-wenang. Walaupun bentuk kedzalimanya berbeda dengan kedzaliman Fir'aun, tapi secara karakter para penguasa itu tidak berbeda dengan Fir'aun. Kekuasaan dia melebihi kekuasaan seorang raja. Seorang rajapun akan tetap tunduk pada hukum, tetapi para penguasa dan para pengikutnya telah berani merubah negara hukum menjadi negara kekuasaan mutlak. Undang-undang telah diselewengkan dan disibir sesuai dengan selera hatinya. Kebebasan pendapat di bungkam dan pers-pun dibredel. Sistem ekonomipun di rubah dari azaz kekeluargaan menjadi ekonomi liberal, dimana dia dan keluarganya beserta konco-konconya saja yang menjadi trilyuner, sementara rakyat sengsara dalam kemiskinan selama berpuluh-puluh tahun.

Lambang keadilan oleh dalam prakteknyapun sangat jauh dari nilai-nilai kemanusiaan, bukan lagi gambar dewi dengan mata tertutup sambil membawa pedang dan timbangan, melainkan diganti dengan lambang pohon beringin. Dia berfsalsafah simbol rimbun daunya akan bisa mengayomi masyarakat, padahal dibawah naungan pohon beringinlah mereka akan menjalankan status Quo-nya.

Para penguasa itu telah menggiring bangsa ini ke jalan yang sesat. Dengan memecah belah berbagai golongan dan kelompok demi kepentingan pribadi dan golonganya sendiri, rakyat diadu domba, dipecahbelah, asalkan tujuan politik mereka tercapai, dan masih banyak lagi kedzaliman-kedzaliman yang lain.

Orde baru tinggal sejarah dan rakyat tidak mau sejarah itu terulang kembali, rakyat hanya ingin reformasi secara total terhadap sistem-sistem yang telah menindas hak-hak rakyat secara kejam. Sistem penguasa yang dzalim masih tampak pada pemerintahan sekarang ini. Ternyata manusia tipe Fir'aun ini secara historiskontekstual senantiasa mencuat kepermukaan dengan aneka ragam bingkai ke-Fir'aunanya sendiri. Tak kurang penguasa-penguasa negara pasca kehancuran Fir'aun masih mementingkan dirinya sendiri sambil menindas dan menganiaya rakyatnya. Begitu pula tak kurang bawahan raja, dari mulai perdana menteri hingga kepala desa, kehidupanya mirip dengan para bangsawan Mesir pada zaman itu, yang secara 
sloganis akan membela rakyat, tapi kenyataanya rakyat miskin akan semakin tertindas.

Firaun-fir'aun kecil masih tumbuh subur dimana-mana, Masyarakat bawah sebagai realitas sosial telah menjadi korban penindasan secara halus, ketimpangan muncul disana sini, agama hanya dijadikan sampul dan bahkan para politikus sering main comot ayat-ayat Allah untuk memuluskan tujuanya.

Pemerintahan sekarang sudah berjalan selama Tiga tahun, tapi belum ada tanda-tanda perubahan yang bisa membawa bangsa dan rakyat ke arah tatanan sosial yang egaliter. Hukum di Indonesia masih bisa dimanipulasi, diplintir, sehingga tidak tampak bentuk aslinya. Pemberantasan korupsi masih sekedar slogan moral, dimana penangananya sering terkesan sambil lalu dan tidak serius. Pelaku korupsi yang sudah jelas didepan mata akan menjadi kabur ketika dilimpahkan ke pengadilan, ironisnya pertimbanganya bersifat politik bukan bersifat hukum lagi.

Rakyat kecil yang mencuri telur bisa dihajar sampai mati, tetapi orang ternama yang sudah jelas melakukan korupsi malah diampuni (mungkin sampai mati) dengan alasan manusiawi. Logika birokrasi hukum tampaknya sudah terbalik, akalnyapun sudah tidak sehat lagi, bagaimana tidak, mengampuni koruptor kelas kakap dianggapnya lebih manusiawi daripada kesengsaraan rakyat, kelaparan, yang semuanya akibat dari ulah para penghissap uang rakyat.

Disatu sisi pemerintah ingin mengentaskan kemiskinan dengan meningkatkan sumberdaya manusia melalui pendidikan, tapi usaha-usaha yang dilakukanya masih pincang. Program bantuan dana operasional yang disalurkan ke sekolah-sekolah seakan-akan menunjukan komitmen pemerintah untuk meningkatkan kualitas pendidikan, tapi sarana penunjang lain dikesampingkan, gedunggedung tua bahkan ada yang sudah roboh menjadi pemandangan yang sungguh sangat ironis. Dan lucunya lagi biaya pendidikan sekarang ini justru sangat mahal, dan semakin tidak terjangkau oleh masyarakat bawah.

Padahal kemiskinan timbul bukan karena kebodohan dan kemalasan, tetapi lebih karena sistem politik, sosial, budaya yang membuat golongan tertentu terpinggirkan dan termiskinkan. 
Pemberian santunan kepada orang miskin dalam situasi seperti sekarang ini tidak akan menyelesaikan masalah, karena bentuk bantuan demikian hanya bersifat menyembuhkan permukaan tidak sampai keakar masalahnya. Ini jelas menimbulkan penindasan baru, yakni penindasan psikologis dari yang kuat terhadap yang lemah.

Dalam banyak hal, pemerintah selalu mengeluarkan kebijakankebijakan tanpa memikirkan lebih jauh imbasnya terhadap rakyat kecil, RUU perburuhan akan semakin mencekik dan akan membunuh rakyat secara perlahan jika RUU itu jadi (disyahkan). Rakyat sebagai korban penindasan semakin dipaksa untuk menerima, perlawananpun akan sia-sia. Allah telah menganugerahi kekayaan alam yang melimpah kepada negeri Indonesia ini untuk bisa dimanfaatkan secara seimbang, bukan dengan cara yang rakus. Penggundulan hutan yang dilakukan oleh tangantangan yang tidak bertanggung jawab akan menyebabkan berbagai bencana yang lagilagi rakyat kecilah yang menanggung akibatnya. Ketika satu mata rantai ekosistem terputus maka banijr akan melanda berbagai wilayah di negeri ini. Birokrasi yang membuat ulah beralasan bahwa banjir terjadi bukan karena penebangan liar, tapi karena hujan yang beberapa hari saja dikatakan terus menerus.

Begitulah secuil potert bangsa kita saat ini. Sangat tragis memang, karena pemimpin yang berkuasa tidak mempunyai rasa kasih yang tidak membangun semangat egaliter kepada rakyatnya. Di negeri kita ini, seorang pemimpin senantiasa berorientasi pada berapa pendapatan yang harus diperolehnya setiap bulan atau selama ia berkuasa; bukan berapa orang yang dapat ia bantu dan selamatkan dari keterbelakangan, kemiskinan dan kebodohan.

Dari gambaran diatas maka dapat ditarik kesimpulan bahwa kita sebagai bangsa Indonesia telah mempunyai karakter-karakter yang tidak jauh beda dengan karakteristik Alu Fir'aun, antara lain sebagai berikut:

a. penguasanya. Tidak sedikit penguasa di negeri ini dari yang terkecil sampai yang teratas, sudah menjadi Fir'aun-Fir'aun kecil, yaitu mereka yang menggunakann kekuasaanya bukan untuk melayani, tapi justru memeras yang lemah, menindas yang kecil dan merampas hakhak orang yang tidak berdaya. 
b. Pemilik kekayaanaya. Orang kaya Alu Fir'aun adalah yang seperti Qarun. Mengumpulkan harta dengan tanpa peduli halal dan haram. Demi mendapatkan uang tidak ragu untuk menyakiti dan membunuh. Menjadikan alam yang gundul dan mengexploitasi seperti halnya kepada pekerja seks komersial dan lain-lain.

c. Cerdik pandainya adalah seperti Haman, yaitu mempersembahkan kecerdasanya untuk mengabdi kepada kedzaliman bukan mengayomi dan membela yang tertindas tapi malah menggunakan ayat-ayat Allah SWT untuk menjustifikasi kezaliman atasnya.

d. Masyarakatnya banyak yang sudah tidak peduli dengan perintah Allah SWT, ketika di masjid membesarkan nama Allah SW'T, tapi diluar masjid malah menyepelekanya. Didalam Masjid menggunakan badan kita untuk beribadah kepada-Nya tapi diluar Masjid dia melakukan maksiat, tangantangan yang digunakan untuk berdo'a adalah tangantangan yang bergelimang dosa. Lidah-lidah yang kita getarkan untuk menyebut nama-Nya adalah lidah yang berlumuran kata-kata kotor. Kepala yang kita rebahkan dalam sujud adalah kepalakepala yang kita dongakan dengan sombong.

Kita semua wajib bersyukur kepada Allah karena dia masih menunjukan kasih sayangnya kepada bangsa ini. Rentetan peristiwa mulai dari tsunami di Aceh, gempa di Yogyakarta, banjir di berbagai daerah, banjir lumpur panas, Tsunami di Pangandaran, gempa di selatan Sumatra, Banten dan Jakarta semoga bisa mengingatkan kita, terlepas bahwa semua itu adalah siklus alam, atau musibah atau bencana ataupun apa namanya, tapi peristiwa-peristiwa itu adalah tanda-tanda akan kemahakuasaan-Nya, sebagaimana tanda-tanda kealaman juga pernah ditunjukan kepada bangsa Mesir dan bangsabangsa terdahulu. Ini menunjukan bahwa kita dan bangsa Indonesia masih diberi kesempatan untuk bertobat dan kembali kejalan Allah secara orisinil, dan kita masih diberi waktu untuk berintrospeksi dan berpikir bahwa kedlaliman akan hancur sebagaimana kehancuran peradaban Fir'aun. 


\section{Penutup}

Beberapa simpulan yang dapat ditarik dari uraian-uraian diatas adalah sebagai berikut:

1. Fir'aun menurut al-Qur'an adalah para penguasa yang dalam menjalankan pemerintahanya memakai sistem yang menindas, penindasan ini didukung oleh para pembesar-pembesarnya (Alu Fir'aun). Ini terbukti ketika sejarah memaparkan bahwa Fir'aun yang pernah hidup pada zaman nabi musa adalah dua orang, yang pertama bernama Ramses II, dan kedua bernama Marneptah, tetapi al-Qur'an dengan sengaja menyembunyikan nama-nama tersebut, sebaliknya Al-Qur'an secara jelas memaparkan karakter raja-raja Mesir itu; antara lain, penyembelihan anak laki-laki, berbuat kezhaliman, penganiayaan terhadap rakyat, kesombongan diri, pemborosan dengan membangun piramida-piramida yang sangat menyengsarakan rakyat miskin, pemerintahan sewenang-wenang, kebijakan memecah belah kelompak masyarakat untuk melayani kepentingan serta perusakan, berbagai kesalahan dan kriminal. Akibat dosa-dosanya kemudian dia dan para pengikutnya ditenggelamkan oleh Allah dilaut merah. Dalam konteks kekinian, Allah akan selalu mengutuk segala bentuk penindasan (tentu saja bentuk penindasan sekarang ini tidak sama dengan yang pernah ada pada zaman Fir'aun) tanpa melihat ruang dan waktu.

2. Musa dibantu saudaranya Harun, diutus oleh Allah untuk membawa ajaran Tauhid kepada bangsa Mesir, tetapi keduanya malah disangka sebagai ahli sihir dan orang gila. Walaupun ancaman bahkan rencana pembunuhan selalu dilakukan Fir'aun, tetapi Musa tidak pernah menyerah. Misi kedua yang diemban Musa adalah Pembebasan Bani Israil dari belenggu penindasan dan perbudakan. Bani Israil sebagai kaum Mustadl'afin dalam kisah tersebut perlu disikapi dengan konteks kekinian, karena istilah Mustadl'afin bukan hanya terdapat pada masa Fir'aun tetapi selalu ada disetiap lapisan masyarakat, sehingga diperlukan langkah kongkrit untuk melepaskan dari cengkeraman para penindas.

3. Kisah Fir'aun tidak bisa dipahami seperti kita membaca teksteks dalam sejarah, karena didalamnya banyak sekali ide moral 
yang harus dimunculkan ditengah bobroknya sistem yang menindas. al-Qur'an adalah kitab petunjuk bagi umat manusia. Banyak sekali pesan moral yang harus kita petik dari hancurnya peradaban-peradaban umat terdahulu dan ini bukan dongeng atau cerita khayal, karena semua bisa dibuktikan lewat bangunan-bangunan peninggalanya. Semua rentetan kisah itu secara esensi membawa ide moral yang sama, dan ini adalah ruh dasar al-Qur'an yang harus dimunculkan kepermukaan. 


\section{Daftar Pustaka}

Akhtar, Shobbir, Islam Agama Semua Zaman, Jakarta: Pustaka Zahro, 2002.

Anwar, Rosihun, Samudra al-Qur'an, Bandung: Pustaka Setia, 2001.

Baidan, Nashrudin, Wawasan Baru Ilmu Tafsir, Yogyakarta: Pustaka Pelajar, 2005.

Chirzin, Muhammad, Permata al-Qur'an, Yogyakarta: Qirtas, 2003.

Djalil , Abdul, Ulumul Qur'an, Surabaya: Dunia Ilmu, 2000.

Engineer, Asghar Ali, Islam dan Theologi Pembebasan, terj. Agung Prihantoro, Yogyakarta: Pustaka Pelajar, 2000.

Ensiklopedi Umum, Jakarta: Penerbit Yayasan Kanisius, 1973.

al-Ghazali, Muhammad, Berdialog dengan al-Quran-Memahami Pesan Suci dalam kehidupan masa kini, Bandung: Mizan, 1999.

Ichwan, Mohammad Nor, Belajar Mudah Ilmu-ilmu al-Qur'an - Seri Buku Daras Ulum Al-Qur'an. 2001.

Kamus Besar Bahasa Indonesia, Departemen Pendidikan dan Kebudayaan Jakarta: Balai Pustaka, 1990.

Khalafullah, M. Ahmad, al-Qur'an Bukan Kitab Sejarah - Seni, Sastra, dan Moralitas dalam Kisah-kisah al-Qur'an, terj. Zuhairi Misrawi dan Anis Maftukhin, Jakarta: Paramadina, 2002.

Kurnia, Muhammad Rahmat, Muhammad Sigit Purnawan Jati, Muhammad Ismail Yusanto, Prinsip-prinsip Pemahaman alQur'an dan Hadits, Jakarta: Khairul Bayan, 2002.

Rahman, Fazlur, Tema Pokok al-Qur'an, terj. Anas Mahyuddin, Bandung: Pustaka, 1993.

, W.C. Smith.....[et-al], Agama untuk Manusia, Yogyakarta: Pustaka Pelajar, 2000.

Riyadi, Hendar, Tafsir Emansipatoris - Arah Baru Studi Tafsir al-Qur'an, Bandung: Pustaka Setia, 2005.

as-Shouwy, Ahmad. [et. al], Mukjizat al-Qur'an dan as-Sunnah tentang IPTEK, Jakarta: Gema Insani Press, 2001. 
Effendi

Suhufi, S. M., Kisah-kisah dalam al-Qur'an, terj. Alwiyah Abdurrahman, Bandung: Penerbit al-Bayan, 1994.

Thalhas, TH., Hasan Basri, Spektrum Saintifika al-Qur'an, Jakarta: Bale Kajian Tafsir al-Qur'an Pase, 2001.

Zaid, Nasr Hamid Abu, Tekstualitas Al-Qur'an-kritik terbadap Ulumul Qur'an, Yogyakarta: Lkis, 2001. 